\title{
Foamed concrete incorporating mineral admixtures and pulverized ceramics: Effect of phase change and mineralogy on strength characteristics
}

\author{
Paul O. Awoyera *, Babamide F. Britto \\ Department of Civil Engineering, Covenant University, PMB 1023 Ota, Nigeria
}

H I G H L I G H T S

- Incorporating ceramics in foamed concrete reduces slump properties.

- Lower amount of Portlandite aids higher strength properties of foamed concrete.

- Ceramics exhibits adequate packing, which is good for ensuring compactness of a cementitious mixture.

\section{A R T I C L E I N F O}

\section{Article history:}

Received 11 June 2019

Received in revised form 21 October 2019

Accepted 1 November 2019

Available online 8 November 2019

\section{Keywords:}

Foamed concrete

Pulverized ceramic

Pozzolan

Phase change

Mineralogy

Compressive strength

Flexural strength

TGA analysis

\begin{abstract}
A B S T R A C T
Different microstructural changes occur in cement based materials as a result of the interaction between the aggregate particles and paste matrix, during mixing, compaction and placement. Such intrinsic modifications, in terms of paste density, interfacial transition zone, permeability and others, tend to improve or lessen the strength properties of concrete. This study evaluates the microstructure, mineralogy, phase change and strength characteristics of foamed concrete containing fly ash and pulverized ceramics. Portion of ceramics, which were generated from floor and wall tile wastes, and finer than $4.75 \mathrm{~mm}$ sieve, along with fly ash, were used as a partial replacement of river sand and cement, respectively. The foaming agent used was aluminum powder. However, other constituents were kept constant. Samples of $150 \mathrm{~mm}$ concrete cubes and $100 \times 100 \times 500 \mathrm{~mm}$ prisms were prepared, and cured in water for 3,7 , and 28 days, for compressive strength and flexural strength determination at the stipulated days. The microstructure, mineralogy and phase change of selected samples were determined using Scanning electron microscope, $\mathrm{X}$-ray diffraction, and Thermogravimetric Analyzer-Differential Scanning Calorimeter, respectively. The ceramics based foamed concrete exhibited lower slump compared to conventional mixture, mainly due to its aggregate higher water absorption capacity. A 100\% ceramics based mix gave strength in somewhat closeness to that of conventional mixture, and it was evidently shown by a lower amount of Portlandite $\left(\mathrm{Ca}(\mathrm{OH})_{2}\right)$ dehydroxylated between 420 and $550{ }^{\circ} \mathrm{C}$ burner temperature for this mixture. The study demonstrates the possibility of incorporating ceramics along with mineral admixtures such as fly ash and aluminum powder for production of foamed concrete.
\end{abstract}

(c) 2019 Elsevier Ltd. All rights reserved.

\section{Introduction}

Foamed concrete is a known building technology that aids the design and construction of lightweight concrete structures. Given that coarse aggregate is completely eliminated from the foamed concrete mixtures, this thus allows the development of highly workable lightweight mixtures. Foamed concrete has a high degree of fluidity, created by mixing cement into a paste (the slurry or mortar), with a pre-formed foam. Such concrete mixtures can be

\footnotetext{
* Corresponding author.

E-mail address: paul.awoyera@covenantuniversity.edu.ng (P.O. Awoyera).
}

useful for construction in regions covered by problematic soil, where building foundation load is often minimized. However, factors such as environmental degradation through release of harmful substances, and sustainability concern, which are associated with the exploration of natural aggregates could limit the expansion of foamed concrete technology. In a way, a considerable number of alternatives have been found in reusing routine industrial rejects and construction wastes for concrete production.

During construction activities, it is known that while about $50 \%$ of raw materials and $40 \%$ of energy are consumed, about $50 \%$ wastes are mostly generated [1]. However, it is noteworthy that through the continuous development of construction and demolition 
wastes, some developed countries now have systems in place for its utilization, such as in the production of nonstructural concrete [24]. Examples could be found in Spain, China and India, among others, where ceramic and glass are processed for applications in recycled concrete $[5,6]$.

Numerous studies have covered the application of construction and demolition wastes in concrete [7-11], with larger part focusing on ceramics as aggregates. In recent years, application of ceramic wastes for production of normal weight concrete and lightweight mortars have been explored [12,13]. Overall, ceramics was found suitable for concrete making, owning to its sound physical and strength characteristics. However, it is uncertain if construction and demolition (C \& D) wastes can be used for making foamed concrete, considering its limitations in terms of high water absorption and presence of air voids [14-16]. Thus, in this study, an attempt is made to evaluate several properties of foamed concrete containing ceramics aggregate and fly ash.

Foamed concrete as a lightweight material depends largely on the foam-to-slurry proportions, and its density can range within 300 and $1600 \mathrm{~kg} / \mathrm{m}^{3}$. The use of sand, pulverized fuel ash (PFA), and quarry residue has been reported as suitable for foamed concrete production $[17,18]$. In foamed concrete, there are at least $20 \%$ (by volume) mechanically entrained foam in a plastic mortar [19].

While there is an advancement in the use of foamed concrete, but its development using ceramics product along with fly ash has not been well treated. Ceramics currently constitutes about $40 \%$ of C \& D wastes, and about $30 \%$ of its content end-up as wastes during production [20-22]. Thus, it would be beneficial to have ceramics incorporated as lightweight aggregate in foamed concrete. Therefore, in this study, attempt has been made to determine microstructure, mineralogy, phase change and strength characteristics of foamed concrete containing fly ash and pulverized ceramics.

\section{Materials and methods}

The constituent materials used in this study include: grade 42.5 Ordinary Portland cement, having $30 \%$ consistency limit, specific gravity of 3.15 , and conforming to specifications $[23,24]$, river sand of sizes under $4.75 \mathrm{~mm}$, aluminum powder (as a foaming agent), and ceramics.

The broken ceramics were cleansed with water (to remove its surface debris), and sun dried before it was crushed into smaller particle sizes with the aid of a metal hammer. But, the portion of ceramics that passed through the $4.75 \mathrm{~mm}$ BS standard aperture size was used as a partial replacement of natural sand. During grading of the ceramics, it was ensured that it reflects river sand properties, for a uniform blending. Moreover, because the material fineness could contribute to its pozzolanic reaction with parent binding agent [25]. Fig. 1 presents the particle size gradation for river sand and ceramic aggregate. As shown, ceramics is slightly finer than the river sand, but overall, the curves fall within the BS 1200 [26] envelope of sand for general purpose mortars. Based on the physical evaluation, it is clear that the ceramic aggregate have promising properties as an artificial material [27]. Table 1 shows the physical properties of the aggregates, which also agrees with the recommended values for a fine aggregate [28,29]. As shown in Table 1, ceramics possessed higher water absorption capacity than river sand, but in effect, this may a have more significant effect on the workability of the mixture, and it may also slightly influence the duration of hydration in the cementitious matrix, as ceramics will provide additional water.

The oxides composition of OPC, fly ash and aluminum used in this study are presented in Fig. 2. Calcium oxide, $\mathrm{CaO}$ (74. 2\%), silica oxide, $\mathrm{SiO}_{2}(70.6 \%)$ and aluminum oxide, $\mathrm{Al}_{2} \mathrm{O}_{3}(85.4 \%)$ are the dominant oxides in cement, fly ash and aluminum, respectively. The hydration mechanism of cementitious material is known to be triggered by the dominancy of $\mathrm{CaO}$, and whereas, silica oxides is responsible for pozzolanic reaction process in supplementary cementitious material. Also, having a huge content of aluminum in the mixtures could slightly influence the tensile properties of the concrete. Following the pozzolanicity assessment procedures for fly ash based on ASTM C618 [30] technique, in that, compositional summation of silica $\left(\mathrm{SiO}_{2}\right)$, aluminate $\left(\mathrm{Al}_{2} \mathrm{O}_{3}\right)$ and ferrite $\left(\mathrm{Fe}_{2} \mathrm{O}_{3}\right)$ should not be less than $70 \mathrm{wt} \%$, it is clear from Fig. 2 that the fly ash used satisfies this condition.

The particle distribution for cement, fly ash and aluminum is shown in Fig. 3. A more homogeneous gradation was exhibited by fly ash and aluminum powder, having values oscillating from 1 to $17 \mu \mathrm{m}$, and highest peaks at $5 \mu \mathrm{m}$ size. The OPC shows a bimodal particle distribution, with one peak between 1 and $3 \mu \mathrm{m}$ and second at $4-8 \mu \mathrm{m}$.

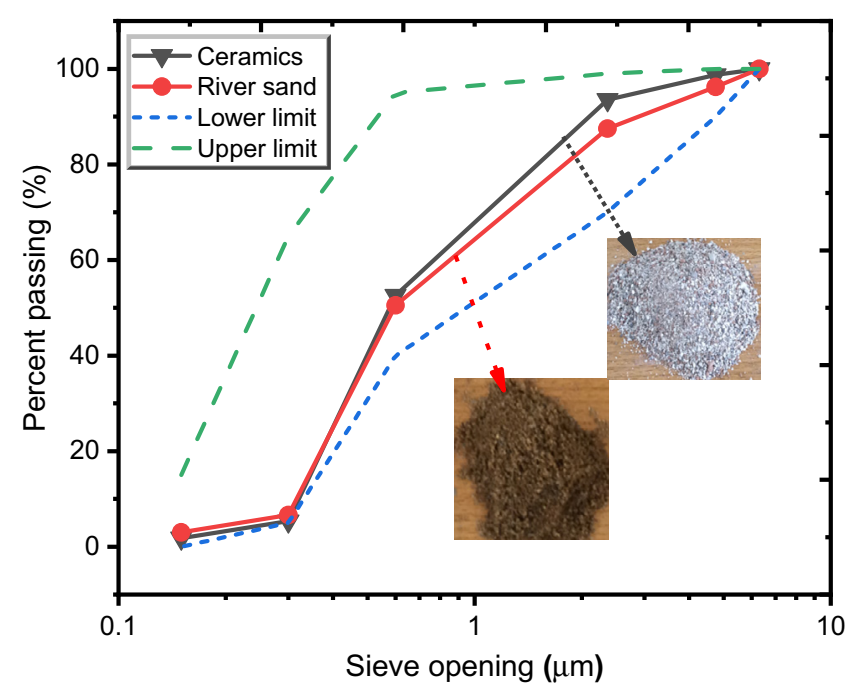

Fig. 1. Distribution of aggregate particles.

Table 1

Aggregates physical properties.

\begin{tabular}{lll}
\hline Properties & Pulverized ceramics & River sand \\
\hline Specific gravity & 2.19 & 2.61 \\
Water absorption (\%) & 2.52 & 2.24 \\
Fineness modulus & 3.26 & 3.22 \\
\hline
\end{tabular}

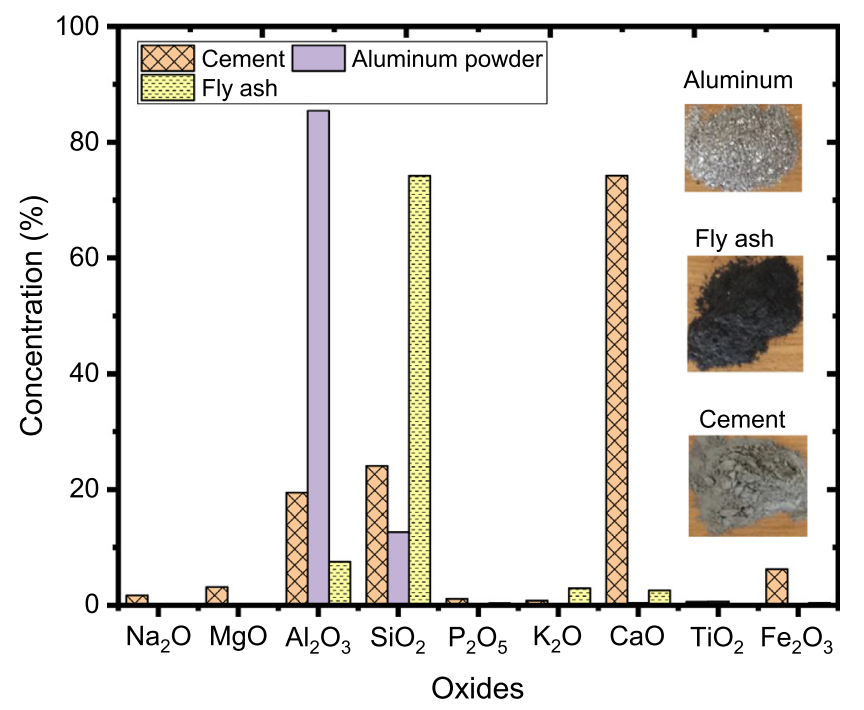

Fig. 2. Oxide composition of cement, fly ash and aluminum powder.

Figure 4 shows the SEM morphology of cement, ceramics, fly ash and aluminum powder, which was determined using the secondary mode. The cement is comprised of angular crystalline particles (Fig. 4a). Ceramics exhibited more of spherical particles (Fig. 4b), while fly ash (Fig. 4c) and aluminum (Fig. 4d) show more of platelike elements.

\subsection{Foamed concrete mixture proportions and preparation}

The mixture design method adopted in this study was in alignment with standard specifications [31,32]. Overall, the criteria include the choice of aggregate for foamed concrete, to ensure optimal passing ability, compressive strength, and water/cement ratio.

Based on the mixture design and material proportioning, four selected mixtures, shown in Table 2, were studied. The mixtures were designed for an M30 grade of concrete, with water/binder ratio, $(\mathrm{w} / \mathrm{b})$, constantly at 0.4 , and the slump values ranging between 100 and $115 \mathrm{~mm}$.

The mixing of concrete followed the criteria of ASTM C685, using a potable water. The foaming agent used was aluminum powder. The workability of each mixture was determined using slump, prior to concrete placement. In each batch, 


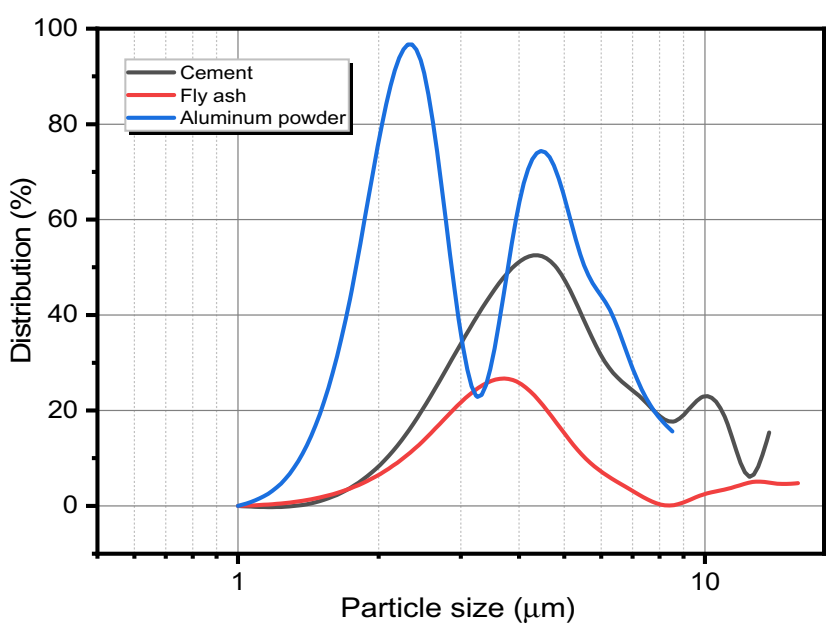

Fig. 3. Distribution of particles of cement, fly ash and aluminum powder.

6 samples of $150 \mathrm{~mm}$ concrete cubes, and 2 numbers of $100 \times 100 \times 500 \mathrm{~mm}^{3}$ prisms were produced. Thus, there were overall 24 concrete cubes and 8 prisms produced, which were cured in water for 3,7 , and 28 days, for compressive strength and flexural strength determination at the stipulated regimes. The curing process occurred at a room temperature of $20 \pm 1{ }^{\circ} \mathrm{C}$. The prisms were reinforced with $12 \mathrm{~mm}$ main bars and $6 \mathrm{~mm}$ stirrup bars.

\subsection{Experimental programme}

The concrete cubes strength was determined after curing had completed, using an ELE compression machine of $2000 \mathrm{kN}$ capacity. An average of 3 cube strength was taken as the compressive strength for a mixture. For the prisms, flexural strength was determined at 28 -day curing regime using a Universal Testing machine. The ultimate failure load was used to determine the flexural strength of beam. The values were obtained via a load cell which was connected to load indicator. Also, the deflection values were measured by the digital dial gauge having a magnetic base. The hardened beam was marked $100 \mathrm{~mm}$ from both ends of beam and centre of beam was marked for fixing the centre point load, where the failure load in the reinforced beam was measured.

The flexural strength of beam was determined using the expression:

Flexural strength, $\frac{\mathrm{Fct}=P * L}{B D^{2}}$

where Fct = Flexural strength of beam specimens, $\mathrm{P}=$ ultimate load applied to beam $(\mathrm{kN}), \mathrm{L}=$ clear length of beam between supports $(\mathrm{mm}), \mathrm{B}=$ width of the specimen $(\mathrm{mm}), \mathrm{D}=$ depth of beam $(\mathrm{mm})$

Concrete crumbs, taken at the centre of the cubes during 28-day compression tests, were used for the microstructural analysis. In this wise, the chemistry of the strength development can be understood. SEM micrograph of selected mixtures were obtained in the secondary electron mode, after the samples were prepared for SEM analysis following the procedures in [33]. The early age mechanism of hydration in blended ceramic - cement paste has been studied [15]. The structural development commenced from hexagonal Portlandite crystals that were linked by ettringite at one day, to calcium silicate hydrate ( $\mathrm{CSH}$ ) and unhydrated alite and belite grains at 7 days.

This study also determined the mineralogy of selected mixtures using X-ray diffractometer. The mineral peaks resulting from the hydration of the concrete were identified. Lastly, Thermogravimetric analysis (TGA) was performed on the hardened samples, taken from the crushed concrete cubes. This was used to determine the quantity of Portlandite $\mathrm{Ca}(\mathrm{OH})_{2}$ formed in the matrix. The test was performed using a 0600 thermogravimetric and differential scanning calorimeter analyser (Fig. 5).

The mortar fragments taken were pulverised and passed through the $75-\mu \mathrm{m}$ sieve. The analyser was set to heat up the sample up to a final temperature of $600{ }^{\circ} \mathrm{C}$ at a rate of $30{ }^{\circ} \mathrm{C}$ per minute up to $300{ }^{\circ} \mathrm{C}$ and $20^{\circ} \mathrm{C}$ per minute thereafter. This test was performed in a nitrogen atmosphere with a purge rate of $20 \mathrm{~mL} / \mathrm{min}$ ute, so as to cut off the effects of degradation and avoid any misleading oxidation reactions from affecting the data.

The test temperature is adequate, owing to the fact that the dehydroxylation of calcium hydroxide occurs at temperature between 420 and $550{ }^{\circ} \mathrm{C}$ [34]. Therefore, the maximum peak occurring at this temperature range represents weight loss caused by the dehyroxylation of $\mathrm{Ca}(\mathrm{OH})_{2}$. Thus, the percent dehydroxylation of $\mathrm{CH}$ (calcium hydroxide) was calculated using Eq. (1) [35]:
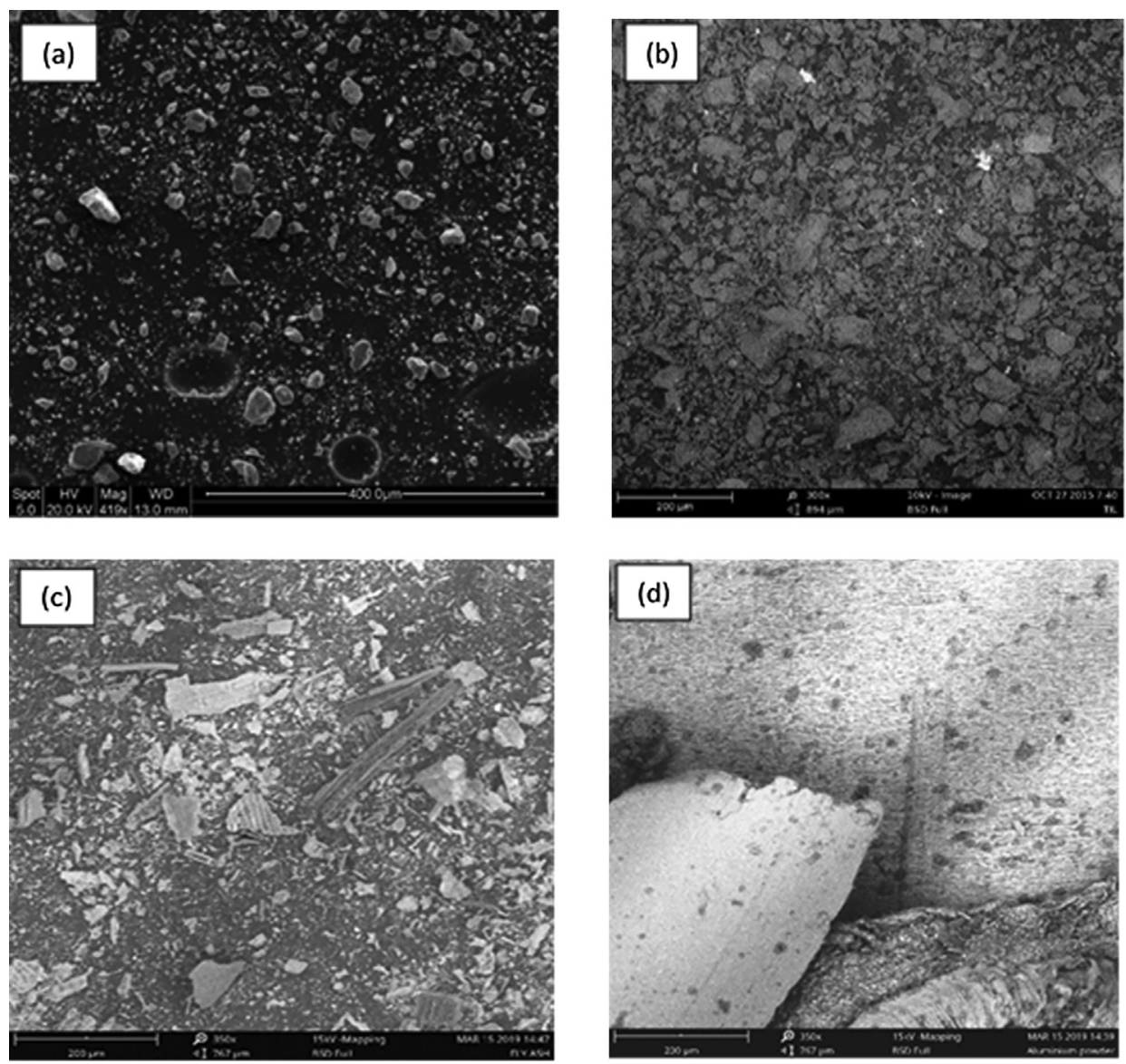

Fig. 4. SEM micrographs (a) cement (b) ceramics (c) fly ash (d) aluminum powder. 
Table 2

Foamed concrete materials mixture proportion.

\begin{tabular}{|c|c|c|c|c|c|c|c|}
\hline $\begin{array}{l}\text { Mixture } \\
\text { ID }\end{array}$ & $\begin{array}{l}\text { Cement } \\
\left(\mathrm{kg} / \mathrm{m}^{3}\right)\end{array}$ & $\begin{array}{l}\text { Fly ash } \\
\left(\mathrm{kg} / \mathrm{m}^{3}\right)\end{array}$ & $\begin{array}{l}\text { River sand } \\
\left(\mathrm{kg} / \mathrm{m}^{3}\right)\end{array}$ & $\begin{array}{l}\text { Pulverized ceramics } \\
\left(\mathrm{kg} / \mathrm{m}^{3}\right)\end{array}$ & $\begin{array}{l}\text { Water } \\
\text { (Litre) }\end{array}$ & $\begin{array}{l}\text { Aluminum powder } \\
\left(\mathrm{kg} / \mathrm{m}^{3}\right)\end{array}$ & $\begin{array}{l}\text { Superplasticizer } \\
\left(\mathrm{kg} / \mathrm{m}^{3}\right)\end{array}$ \\
\hline FCO & 374 & 45 & 1881 & 0 & 165 & 0 & 0 \\
\hline FC1 & 374 & 45 & 1881 & 0 & 165 & 1.5 & 1.87 \\
\hline FC3 & 374 & 45 & 941 & 941 & 165 & 1.5 & 1.87 \\
\hline FC4 & 374 & 45 & 0 & 1881 & 165 & 1.5 & 1.87 \\
\hline
\end{tabular}

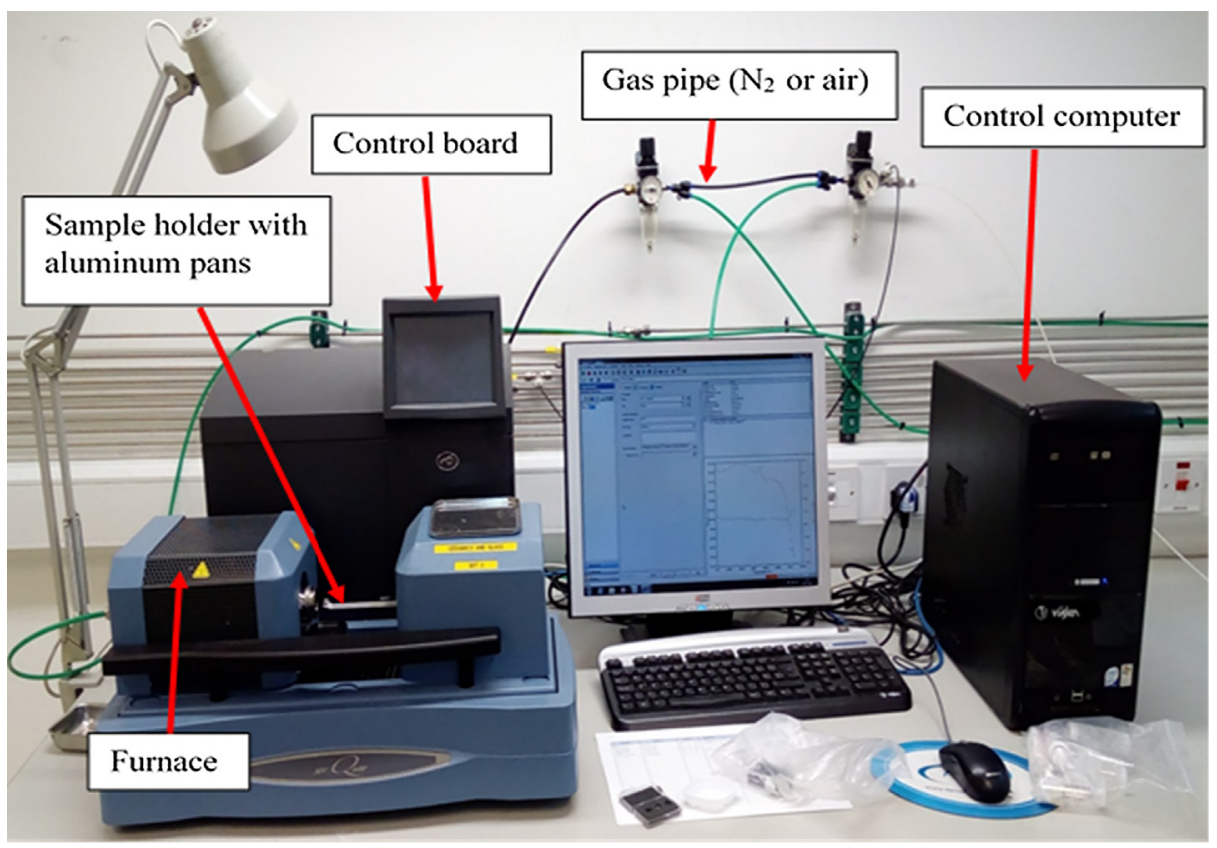

Fig. 5. SDT Q600 Thermogravimetric Analyzer (TGA) and Differential Scanning Calorimeter (DSC).

$\mathrm{CH} \%$ de - hydroxylation $=\frac{74}{18}$

where 74 and 18 are the molecular weights of $\mathrm{CH}$ and $\mathrm{H}_{2} \mathrm{O}$ respectively, and

$\mathrm{A}$ is the area under the derivative weight loss curve which corresponds to the total mass lost due to the dehydroxylation of $\mathrm{CH}$.

\section{Results and discussions}

\subsection{Workability}

The slump values for the mixtures is presented in Fig. 6. Higher slump values were obtained for mixtures FCO and FC1 (containing river sand) than other mixtures FC3 and FC4, having ceramics. From this result, there is tendency that part of the water meant for ensuring flowability of the mixture was retained by ceramics, owing to its high water absorption capacity. However, the entire mixtures fulfilled the workability deign for this study.

\subsection{Strength development}

Fig. 7 presents the compressive strength of the concrete mixtures, as obtained after 7 and 28 days curing regimes. It was evident that rapid development in strength occurred between the initial and final testing period, at about $46 \%$ increment rate for all mixtures. The compressive strength generally increased with increasing curing regime, which is owing to hydration phenomenon and structural transformation in the matrix. As shown,

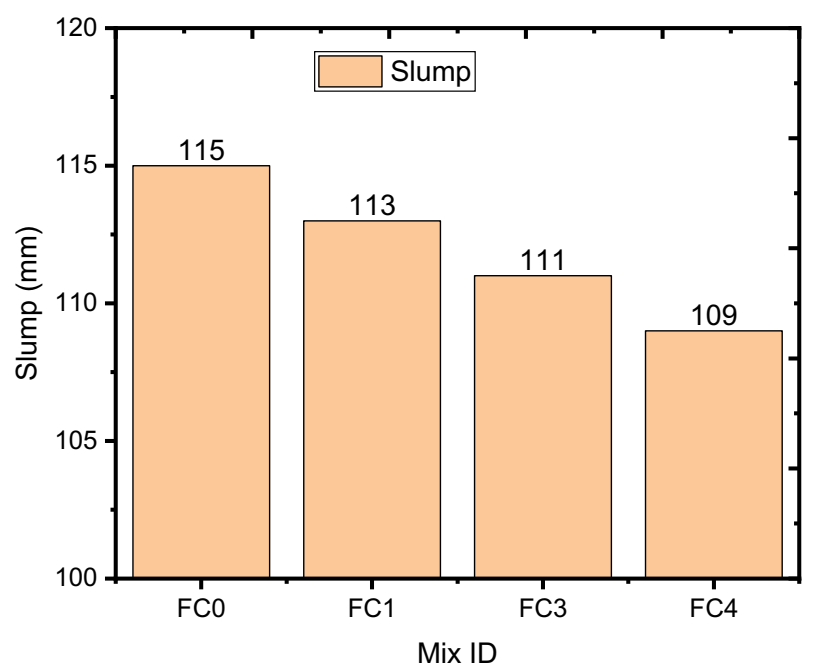

Fig. 6. Slump of tested foamed concrete mixtures.

sample containing $100 \%$ ceramics as fine aggregate (FC4), developed strength in close range with the river sand based mixture (FC0). Ceramics can therefore be said to have enhanced the ductility and compactness of the concrete. Also, because ceramics have high silicate and alumina contents, it might also exhibit some 


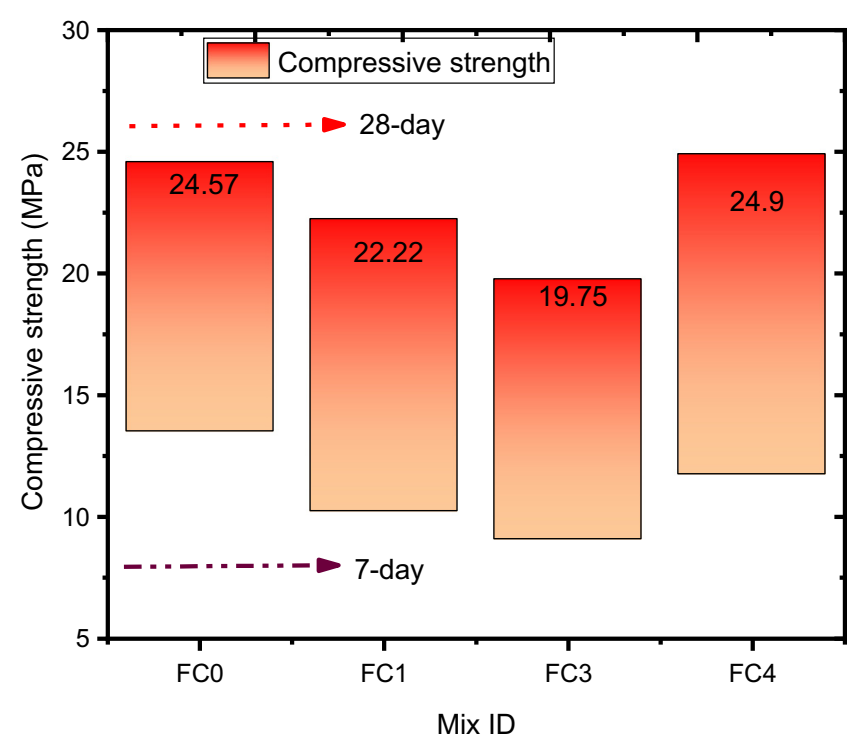

Fig. 7. Compressive strength of foamed concrete mixtures.

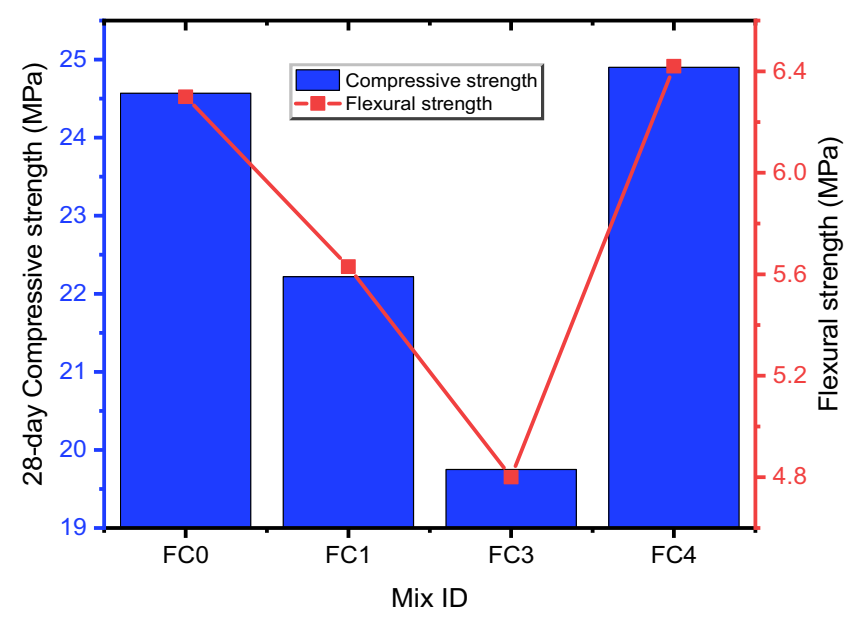

Fig. 8. Flexural strength and compressive strength of mixtures.

pozzolanic properties in the mixture. Thus, there is possibility of the high alkali in the pore solution to activate the silicate and alumina ions in the ceramic thereby contributing to the strength. The effect of aluminum powder was not significant in the mixtures. However, fly ash is certainly responsible for the pozzolanic reaction and filler effect, within all the tested samples. Moreover, the water-binder ratio of 0.4 utilized helped to reduce the porosity of the mixtures. Although, porosity might also be diminished by the formation of $\mathrm{CSH}$ in the free pores of the concrete matrix (space initial occupied of water) [36]. The result of the flexural strength, presented along with the 28-day compressive strength is shown in Fig. 8. The data clearly revealed a similar trend between the two strength values. FCO and FC4 mixtures are somewhat closely linked.

\subsection{Microscale analysis results}

The SEM morphology of selected mixtures (FC0 and FC4) that produced higher strength values are presented in Fig. 9. After 28 - days of hydration, there could be seen in FCO mixtures (Fig. 9a), ettringite networks surrounded by densified calcium silicate hydrate $(\mathrm{CSH})$. Some unhydrated minerals are also appearing in the micrograph. For FC4 (Fig. 9b), a very large and plate-like Portlandite minerals, which also appeared layered could be seen. The surface profile of the two mixtures is shown in Fig. 10. A rough surface was observed in FC0 mixture (Fig. 10a), which is a direct implication of ettringite links and disjointed particles. On the other hand, a fairly smooth surface was seen in the FC4 mixture (Fig. 10b), which is obviously due to the layered spots filled by Portlandite.

A TA universal analysis 2000 software was utilized for analyzing weight loss-temperature change data, gotten from the thermogravimetric inbuilt software. The result of the TGA analysis for the control concrete and a sample of foamed concrete containing pulverized ceramic particles are shown in Figs. 13 and 14, respectively. The clear peaks that occur at 25 and 123.3 oC on the graphs represent dehydration of matrix pore water [37]. However, the emphasis is made on the third peak at $420-550^{\circ} \mathrm{C}$, which represent the dehydroxylation of $\mathrm{CH}$ [34].

For the FC0 and FC4 mixture, $432.44{ }^{\circ} \mathrm{C}$ and $426.76{ }^{\circ} \mathrm{C}$, respectively, were the peaks corresponding to the $\mathrm{CH}$ dehydroxylation (Figs. 13 and 14 ). Thus, $1.47 \% / \mathrm{min}$ and $1.333 \% / \mathrm{min}$ were their resulting weight losses.

Thus, mixtures FC0 and FC4 produced $6.08 \%$ and $5.48 \%$ (using equation 1) $\mathrm{CH}$ dehydroxylation, respectively. A lower amount of $\mathrm{CH}$ dehydroxylation for FC4 mixture is attributable to a fairly complete hydration process. Moreover, the demonstrated the development of CSH gels, as evidently proven by the slightly higher strength in FC4 mixture.
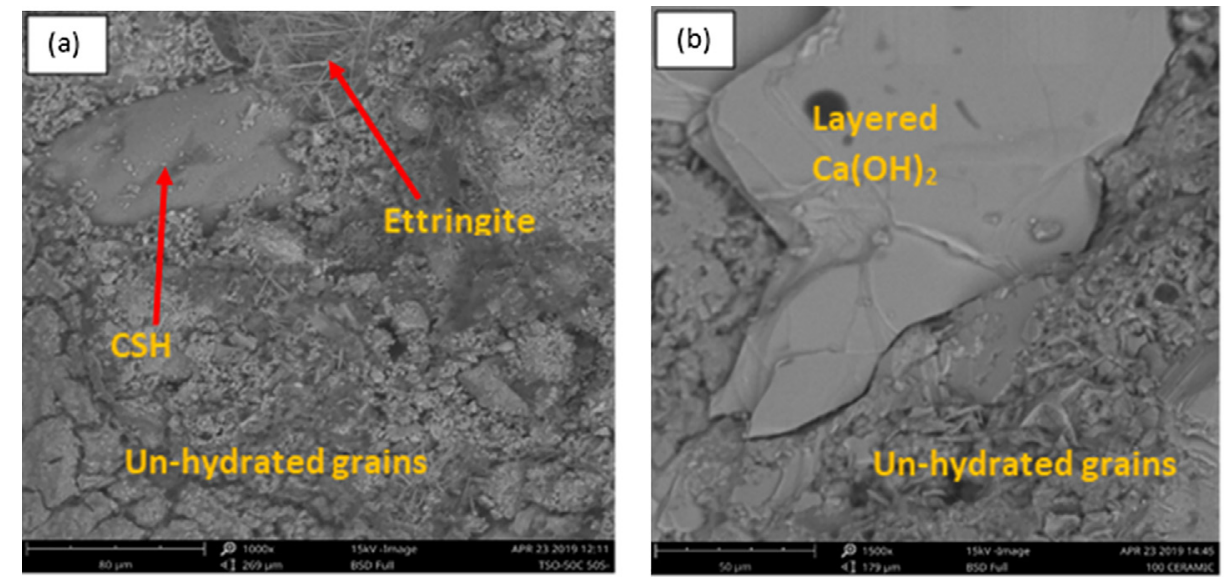

Fig. 9. Morphology of selected foamed concrete mixtures (a) FC0 (b) FC4. 

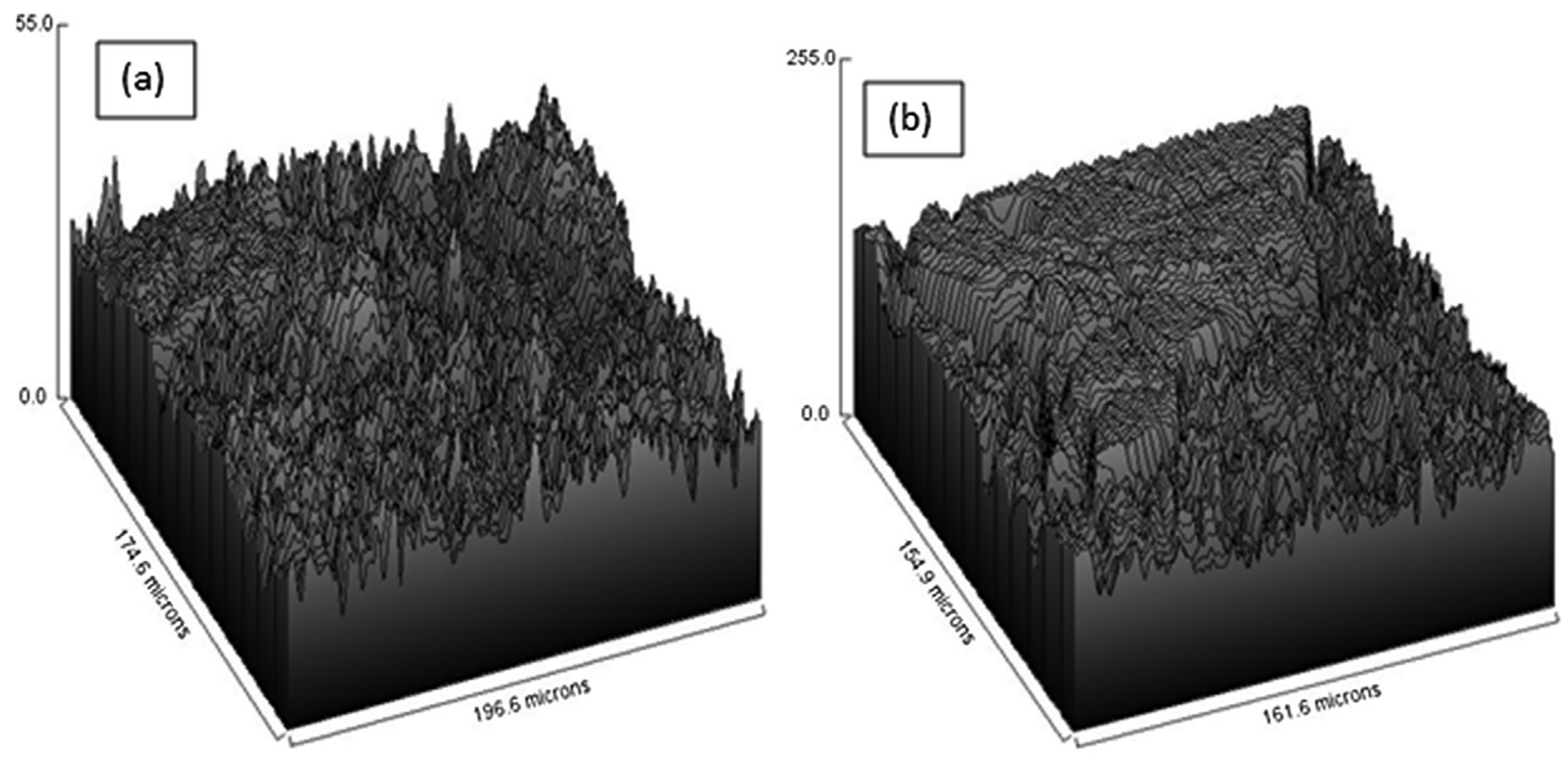

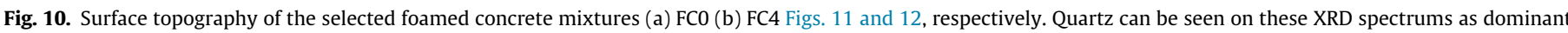

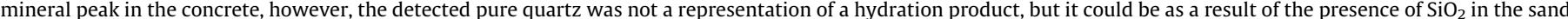

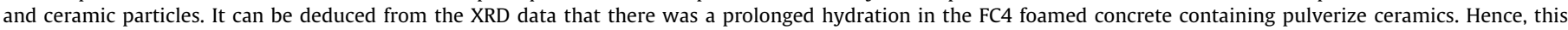
further corroborates the mechanical strength performance of the concrete samples.

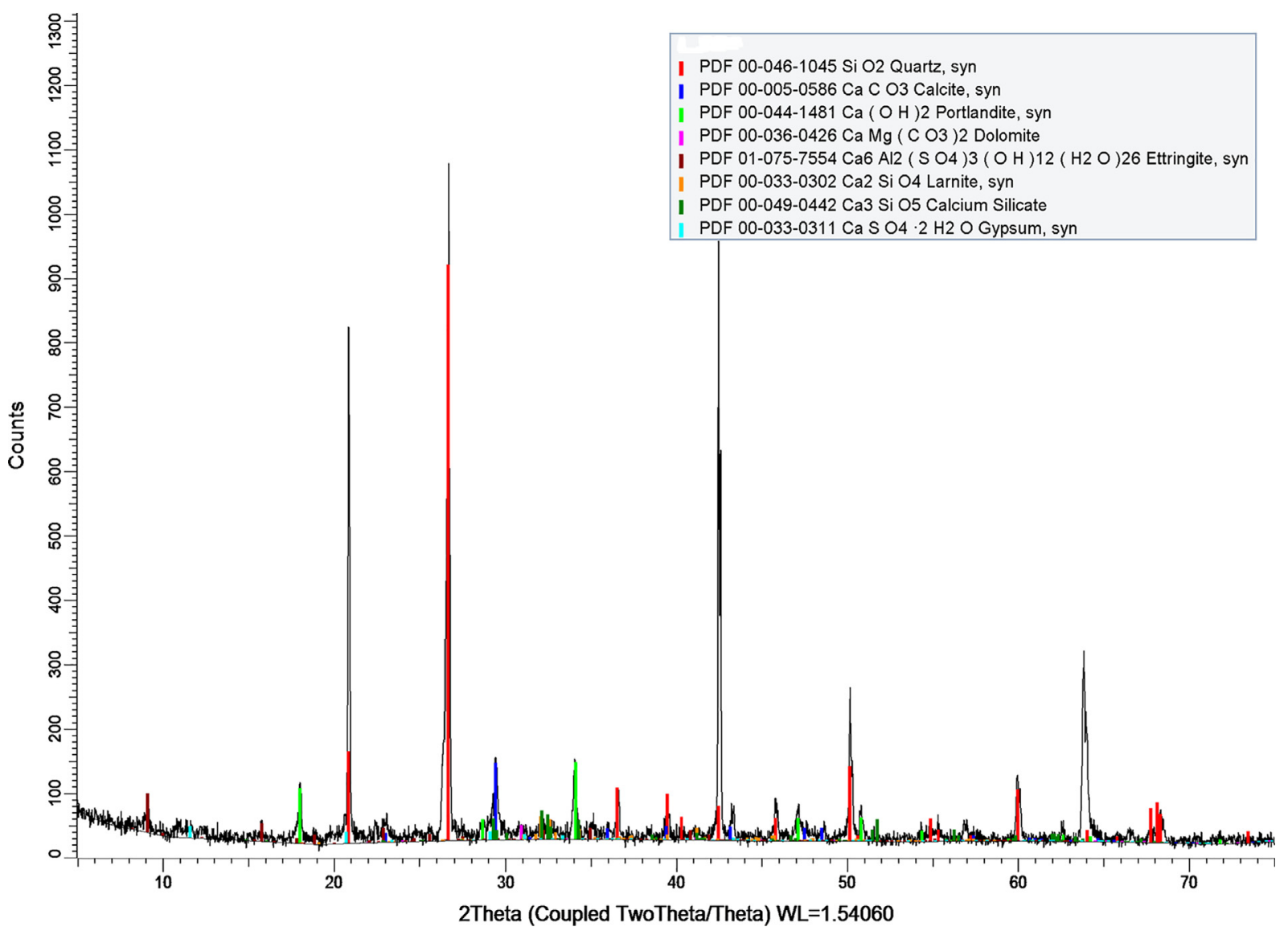

Fig. 11. XRD spectra, showing the mineralogy of FCO mixture. 


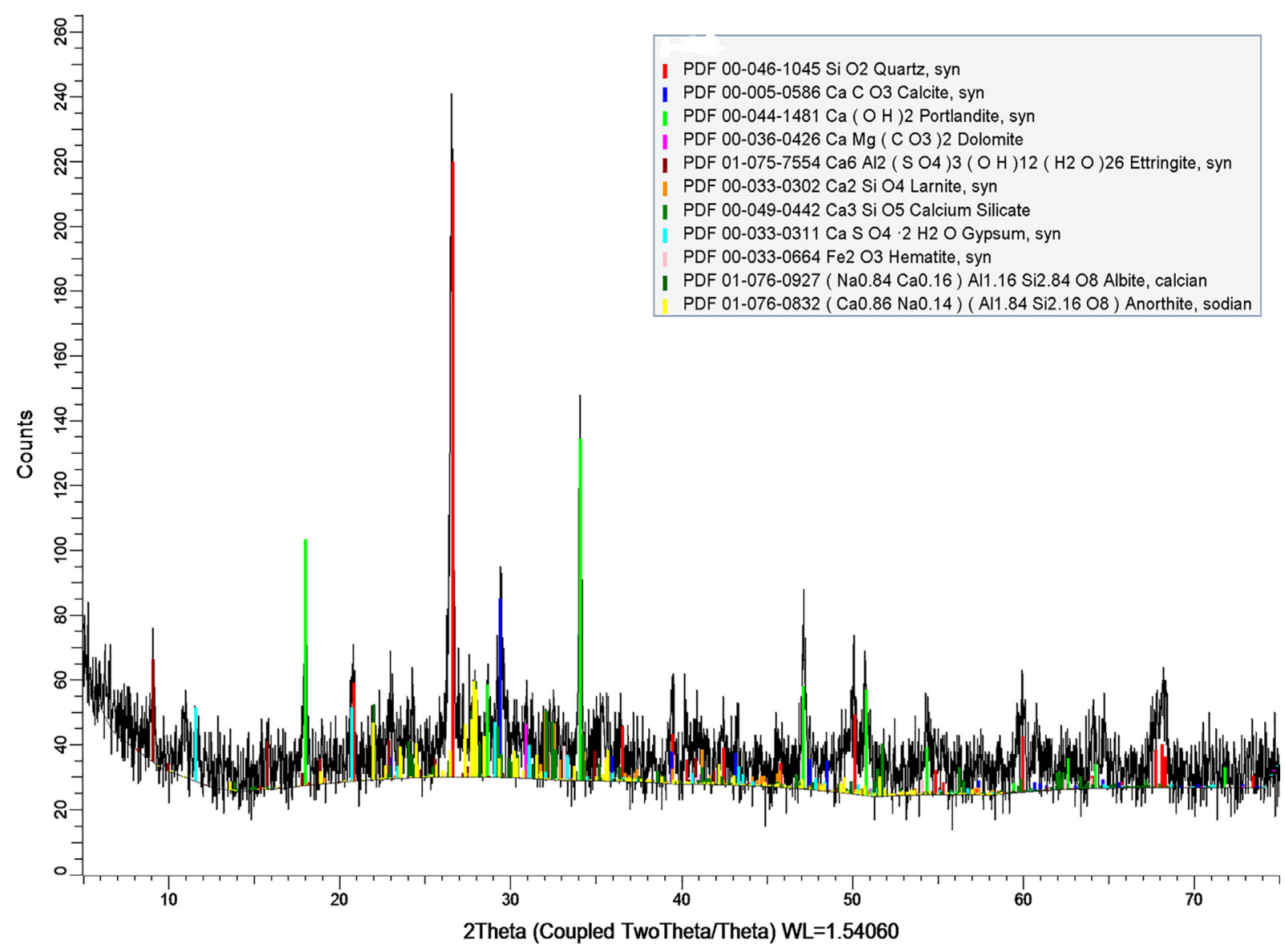

Fig. 12. Mineralogy of foamed concrete containing pulverized ceramic (FC4).

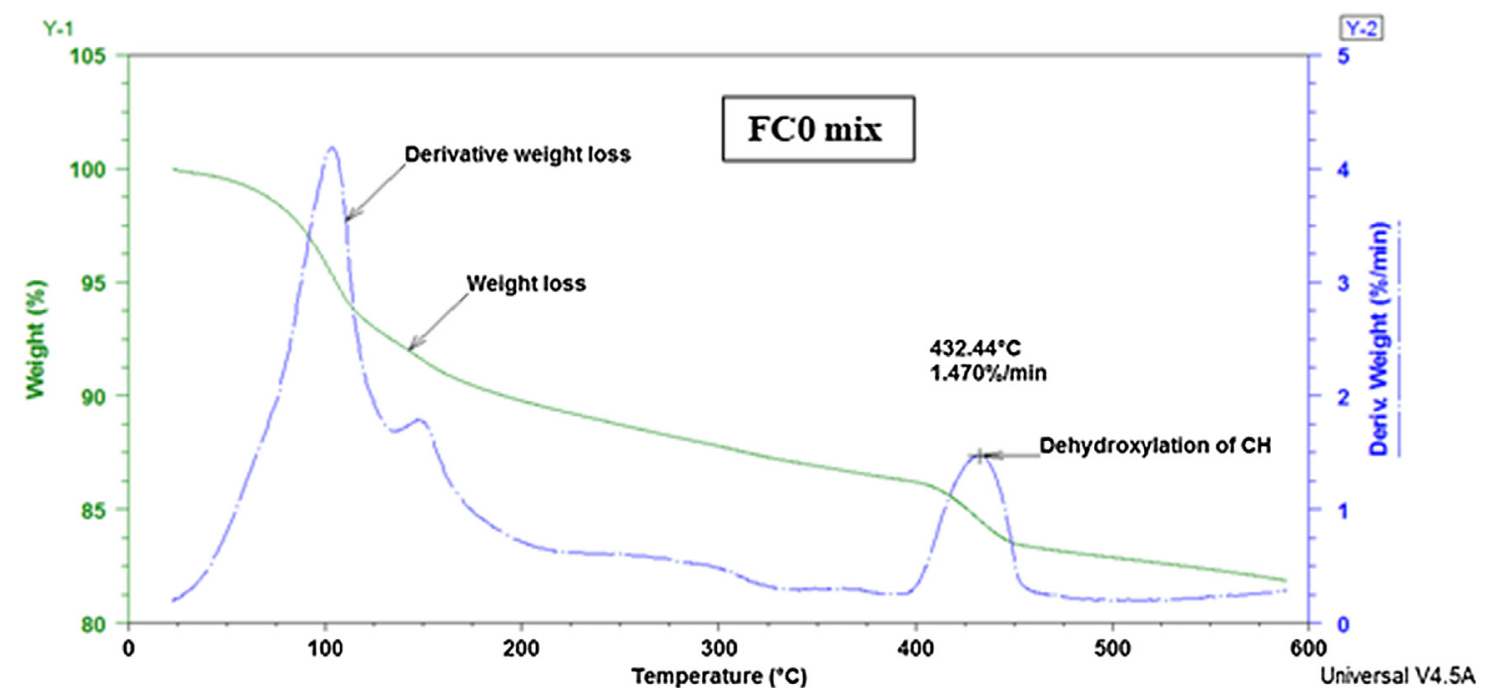

Fig. 13. Combined weight loss and derivative weight loss for FCO mixture.

\section{Conclusion}

This study investigates the microstructure, mineralogy, phase change and strength properties of foamed concrete incorporating fly ash and pulverized ceramic particles. The conclusions drawn from the study are as follow; i. the workability (slump value) of mixtures containing ceramics particles were lesser than that of the river sand based mixtures. Thus, the study showed that higher water absorption capacity of ceramics was responsible for low slump, as part of the mixing water has been trapped-in ceramics aggregates. 


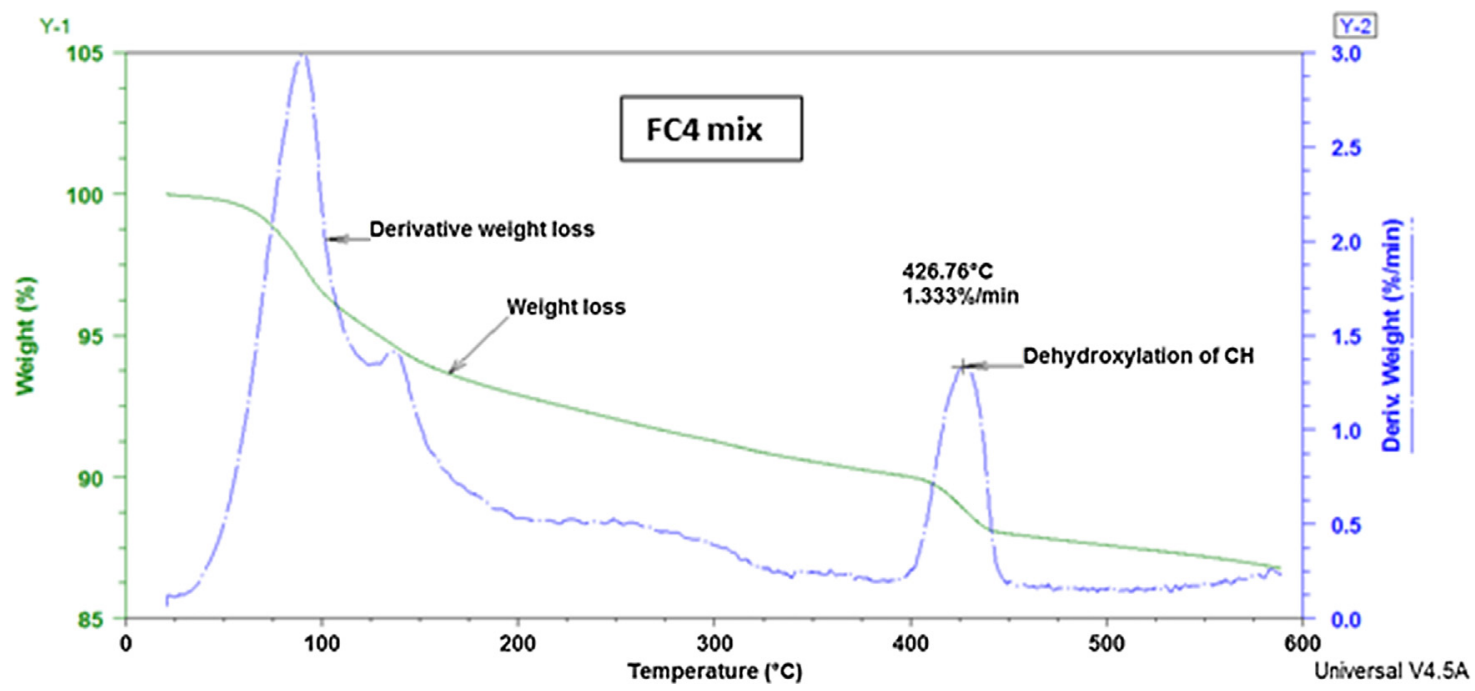

Fig. 14. Combined weight loss and derivative weight loss for foamed concrete containing ceramic particles (FC4 mixture).

ii. the study has revealed that a $100 \%$ aggregate comprising of pulverized ceramics as foamed concrete aggregate could produce strength somewhat close to that of the conventional mixture. It was deduced, based on assessment of SEM micrographs, that aggregate parking, and filler effect of fly ash enhanced the mechanism of hydration and compactness of the matrix microstructure. In addition, the $100 \%$ ceramics based concrete showed a smoother contour topography, which was an evidence that plate-like Portlandite layers were developed.

iii. Based on the mineralogy and phase change assessment, it was clearly shown that there was agreement between both XRD and TGA outputs for each of $100 \%$ river sand, and $100 \%$ ceramics based foamed concrete. There was an indication that the $100 \%$ ceramics based concrete demonstrated fairly complete hydration than the $100 \%$ river sand based concrete. This assertion was backed by the fact that there was a lower amount of $\mathrm{Ca}(\mathrm{OH})_{2}$ dehydroxylated between 420 and $550{ }^{\circ} \mathrm{C}$ burner temperature.

Overall, the study has demonstrated the possibility of incorporating ceramics along with mineral admixtures such as fly ash and aluminum powder for production of foamed concrete. In essence, it has been shown that ceramics exhibits adequate packing in the tested mixtures, which is good for ensuring compactness of a cementitious mixture.

\section{Declaration of Competing Interest}

The authors declare that they have no known competing financial interests or personal relationships that could have appeared to influence the work reported in this paper.

\section{Acknowledgement}

The funding (NGCN-2016-139) received from the Commonwealth Scholarship Commission in the United Kingdom during the first phase of the research programme is well appreciated.

\section{Appendix A. Supplementary data}

Supplementary data to this article can be found online at https://doi.org/10.1016/j.conbuildmat.2019.117434.

\section{References}

[1] F. Margarido, Environmental Impact and Life Cycle Evaluation of Materials: Materials for Construction and Civil Engineering, Springer, Switzerland, 2015.

[2] S. Achtemichuk, J. Hubbard, R. Sluce, M.H. Shehata, The utilization of recycled concrete aggregate to produce controlled low-strength materials without using Portland cement, Cem. Concr. Compos. 31 (2009) 564-569, https://doi. org/10.1016/j.cemconcomp.2008.12.011.

[3] W.H. Kwan, M. Ramli, K.J. Kam, M.Z. Sulieman, Influence of the amount of recycled coarse aggregate in concrete design and durability properties, Constr. Build. Mater. 26 (2012) 565-573, https://doi.org/10.1016/j.conbuildmat.2011.06.059.

[4] C. Rodríguez, C. Parra, G. Casado, I. Miñano, F. Albaladejo, F. Benito, I. Sánchez, The incorporation of construction and demolition wastes as recycled mixed aggregates in non-structural concrete precast pieces, J. Clean. Prod. 127 (2016) 152-161, https://doi.org/10.1016/j.jclepro.2016.03.137.

[5] C.-S. Poon, D. Chan, The use of recycled aggregate in concrete in Hong Kong Resour. Conserv. Recycl. 50 (2007) 293-305, https://doi.org/10.1016/j. resconrec.2006.06.005.

[6] A.K. Padmini, K. Ramamurthy, M.S. Mathews, Influence of parent concrete on the properties of recycled aggregate concrete, Constr. Build. Mater. 23 (2009) 829-836, https://doi.org/10.1016/j.conbuildmat.2008.03.006.

[7] P.O. Awoyera, A.R. Dawson, N.H. Thom, J.O. Akinmusuru, Suitability of mortars produced using laterite and ceramic wastes: mechanical and microscale analysis, Constr. Build. Mater. 148 (2017), https://doi.org/10.1016/j.conbuild mat.2017.05.031.

[8] T. Sathanandam, P.O. Awoyera, V. Vijayan, K. Sathishkumar, Low carbon building: experimental insight on the use of fly ash and glass fibre for making geopolymer concrete, Sustain. Environ. Res. 27 (2017) 146-153, https://doi. org/10.1016/j.serj.2017.03.005.

[9] J. Lucas, J. de Brito, R. Veiga, C. Farinha, The effect of using sanitary ware as aggregates on rendering mortars' performance, Mater. Des. 91 (2016) 155164, https://doi.org/10.1016/j.matdes.2015.11.086.

[10] C. Medina, M.I. Sánchez de Rojas, C. Thomas, J.A. Polanco, M. Frías, Durability of recycled concrete made with recycled ceramic sanitary ware aggregate. Inter-indicator relationships, Constr. Build. Mater. 105 (2016) 480-486, https://doi.org/10.1016/j.conbuildmat.2015.12.176.

[11] A. Halicka, P. Ogrodnik, B. Zegardlo, Using ceramic sanitary ware waste as concrete aggregate, Constr. Build. Mater. 48 (2013) 295-305, https://doi.org/ 10.1016/j.conbuildmat.2013.06.063.

[12] Z. Pavlík, M. Pavlíková, J. Fořt, T. Kulovaná, R. Černý, Reuse of waste ceramic powder with a high content of amorphous phases as partial replacement of Portland cement, Adv. Mater. Res. 905 (2014) 212-215.

[13] P.O. Awoyera, J.O. Akinmusuru, A.R. Dawson, J.M. Ndambuki, N.H. Thom, Microstructural characteristics, porosity and strength development in ceramic-laterized concrete, Cem. Concr. Compos. 86 (2018), https://doi.org/ 10.1016/j.cemconcomp.2017.11.017.

[14] P. Favaretto, G.E.N. Hidalgo, C.H. Sampaio, R.D.A. Silva, R.T. Lermen, Characterization and use of construction and demolition waste from south of brazil in the production of foamed concrete blocks, Appl. Sci. 7 (2017), https://doi.org/10.3390/app7101090.

[15] P.O. Awoyera, J.O. Akinmusuru, A. Moncea, Hydration mechanism and strength properties of recycled aggregate concrete made using ceramic blended cement, Cogent Eng. 4 (2017), https://doi.org/10.1080/23311916.2017.1282667.

[16] P.O. Awoyera, U.C. Okoro, Filler-ability of highly active metakaolin for improving morphology and strength characteristics of recycled aggregate concrete, Silicon (2019), https://doi.org/10.1007/s12633-018-0017-8. 
[17] C.K. Man, H.S. Yeung, The effects of using pulverized fuel ash as partial substitute for cement in concrete, Sci. Total Environ. 196 (1997) 171-176, https://doi.org/10.1016/S0048-9697(96)05418-6.

[18] S.K. Lim, C.S. Tan, B. Li, T.-C. Ling, M.U. Hossain, C.S. Poon, Utilizing high volumes quarry wastes in the production of lightweight foamed concrete, Constr. Build. Mater. 151 (2017) 441-448, https://doi.org/10.1016/j.conbuild mat.2017.06.091.

[19] S. Wei, C. Yiqiang, Z. Yunsheng, M.R. Jones, Characterization and simulation of microstructure and thermal properties of foamed concrete, Constr. Build. Mater. 47 (2013) 1278-1291, https://doi.org/10.1016/j.conbuildmat.2013.06.027.

[20] P.O. Awoyera, J.O. Akinmusuru, J.M. Ndambuki, S.S. Lucas, Benefits of using ceramic tile waste for making sustainable concrete, J. Solid Waste Technol. Manage. 43 (2017), https://doi.org/10.5276/JSWTM.2017.233.

[21] E. Vejmelkova, T. Kulovana, M. Keppert, P. Konvalinka, M. Ondracek, M. Sedlmajer, R. Cerny, Application of Waste Ceramics as Active Pozzolana in Concrete Production, in: IACSIT Coimbatore Conf., 2012.

[22] P.O. Awoyera, J.O. Akinmusuru, J.M. Ndambuki, Green concrete production with ceramic wastes and laterite, Constr. Build. Mater. 117 (2016) 29-36 https://doi.org/10.1016/j.conbuildmat.2016.04.108.

[23] BS 12:1989, Specification for ordinary and rapid-hardening Portland cement Br. Stand. London, UK. (n.d.).

[24] part 1 NIS 444, Composition, specifications and conformity criteria for common cements, Niger. Ind. Stand. Center, Niger. 2003.

[25] G.M.S. Islam, M.H. Rahman, N. Kazi, Waste glass powder as partial replacement of cement for sustainable concrete practice, Int. J. Sustain. Built Environ. 6 (2017) 37-44, https://doi.org/10.1016/j.ijsbe.2016.10.005.

[26] BS 1200, Specifications for building sands from natural sources, 1975.

[27] J. Wang, E. Liu, L. Li, Characterization on the recycling of waste seashells with Portland cement towards sustainable cementitious materials, J. Clean. Prod. 220 (2019) 235-252, https://doi.org/10.1016/j.jclepro.2019.02.122.
[28] BS 1377-2, Methods of test for soils for civil engineering purposes. Classification tests, Br. Stand. London, UK. 1990.

[29] BS 812-110, Methods for determination of aggregate crushing value (ACV), Br. Stand. London, UK. 1990.

[30] ASTM C618, Standard specification for coal fly ash and raw or calcined natural pozzolan for use in concrete, Am. Soc. Test. Mater. (2008).

[31] ACI 213R, Guide for Structural Lightweight-Aggregate Concrete, 2003.

[32] ACI, 211.2, Standard Practice for Selecting Proportions for Structural Lightweight Concrete, 1998.

[33] S. Erdem, A.R. Dawson, N.H. Thom, Microstructure-linked strength properties and impact response of conventional and recycled concrete reinforced with steel and synthetic macro fibres, Constr. Build. Mater. 25 (2011) 4025-4036, https://doi.org/10.1016/j.conbuildmat.2011.04.037.

[34] H. El-Hassan, Y. Yixin Shao, Z. Ghouleh, Reaction products in carbonationcured lightweight, Concr. J. Mater. Civ. Eng. 25 (2013) 799-809.

[35] P.H.R. Borges, J.O. Costa, N.B. Milestone, C.J. Lynsdale, R.E. Streatfield, Carbonation of $\mathrm{CH}$ and $\mathrm{C}-\mathrm{S}-\mathrm{H}$ in composite cement pastes containing high amounts of BFS, Cem. Concr. Res. 40 (2010) 284-292, https://doi.org/10.1016/ j.cemconres.2009.10.020.

[36] S. Omary, E. Ghorbel, G. Wardeh, Relationships between recycled concrete aggregates characteristics and recycled aggregates concretes properties, Constr. Build. Mater. 108 (2016) 163-174, https://doi.org/10.1016/ j.conbuildmat.2016.01.042.

[37] A.J. Buttress, D.A. Jones, C. Dodds, G. Dimitrakis, C.J. Campbell, A. Dawson, S.W. Kingman, Understanding the scabbling of concrete using microwave energy, Cem. Concr. Res. 75 (2015) 75-90, https://doi.org/10.1016/j.cemconres. 2015.04.009. 